\title{
Studi Deskriptif Tidak Tercapainya Bonus Demografi di Kabupaten Landak
}

\author{
Meiran Panggabean* \\ Universitas Tanjungpura
}

\begin{abstract}
This study aims to identify and analyze the cause of not achieving the demographic bonus in District of Landak from perspective of population-dynamics. To accomplish the study purposes, this study used the basic data from Population Census 2010 and used spectum program as the analysis tool. The conclusion showed that the cause of not achieving the demographic bonus is closely related to the high of fertility (TFR), the relatively low number of mortality (CDR, IMR and MMR) and negative net migration.
\end{abstract}

Keywords: Demographic bonus, Fertility, Mortality, Dynamics of population

\section{PENDAHULUAN}

Salah satu buah dari keberhasilan pembangunan kependudukan di Indonesia adalah menurunnya tingkat kelahiran total (Total Fertility Rate/TFR) melalui program Keluarga Berencana adalah bertambahnya penduduk usia produktif (usia 45-64 tahun) di satu sisi dan berkurangnya penduduk usia non produktif (usia $<15$ tahun dan $65^{+}$tahun) di sisi lain. Sehingga angka rasio ketergantungan (dependency ratio/DR) semakin rendah.

Selama empat dasawarsa pembangunan kependudukan di Indonesia tampak keberhasilan pada penurunan TFR dari 5,5 anak per wanita tahun 1970 menjadi 1,98 anak per wanita tahun 2010. Selain keberhasilan pada aspek fertilitas, juga pada saat yang sama dirasakan keberhasilan dalam aspek mortalitas berkat kemajuan pembangunan kesehatan. Angka kematian bayi (Infant Mortality Rate/IMR) menunjukkan trend menurun dari 97/1000 kelahiran hidup (1991) menjadi 40/1000 kelahiran hidup (2012) dan 32/1000 kelahiran hidup (2015).

Konsekuensi perubahan pada aspek fertilitas, mortalitas dan migrasi penduduk adalah bergesernya struktur umur penduduk yang pada gilirannya berpengaruh pada angka rasio ketergantungan (Dependency Ratio/DR). Dependency Ratio Indonesia menurun dari 80,0 persen tahun 1970 menjadi 51,3 persen tahun 2010. Angka DR diperkirakan akan

\footnotetext{
* Korespondensi: Meiran Panggabean, Jurusan Ilmu Ekonomi, Fakultas Ekonomi dan Bisnis, Universitas Tanjungpura, Jalan Prof. DR. H. Hadari Nawawi, Pontianak 78124, Indonesia. Email: edampang@ yahoo. co.id
} 
menurun terus pada masa datang hingga di bawah 50\%. Penurunan angka DR merupakan tanda-tanda tercapainya bonus demografi.

Beberapa definisi mengenai bonus demografi merujuk pada fenomena penambahan jumlah penduduk usia kerja yang membawa keuntungan bagi perekonomian. Bonus demografi oleh Chandrasekhar, et al (2006) didefinisikan sebagai sebuah penambahan penduduk pada kelompok usia kerja yang walaupun meningkatkan jumlah penduduk total, dipandang sebagai sebuah keuntungan yang tidak terelakkan. Kalau Adioetomo (2007) menyebutnya keuntungan ekonomis yang disebabkan oleh penurunan angka ketergantungan sebagai hasil proses penurunan kematian bayi dan penurunan fertilitas jangka panjang.

Bonus demografi terjadi pada tahapan dimana kondisi struktur umur penduduk menjadikan ketergantungan penduduk berada pada tingkat yang rendah (DR < 50). Angka DR merupakan perbandingan antara jumlah penduduk usia produktif (15-64 tahun) dengan non produktif (usia $<15$ dan usia $>64$ tahun). Angka DR menjelaskan seberapa banyak orang usia non produktif yang hidupnya harus ditanggung oleh kelompok usia produktif.

Bonus demografi dapat dimanfaatkan untuk meningkatkan produktivitas dan pertumbuhan ekonomi, dengan memanfaatkan jumlah usia produktif yang lebih tinggi. Inilah fase yang disebut Adioetomo (2005) sebagai window of opportunity (jendela kesempatan), yaitu populasi penduduk yang meski dalam jumlah banyak namun disertai dengan penduduk usia produktif yang jauh lebih besar dibandingkan penduduk usia muda dan lanjut usia.

Meskipun diperkirakan Indonesia akan mencapai bonus demografi mulai tahun 2015, namun dalam realitanya, di beberapa propinsi dan kabupaten/kota telah masuk pada era 'bonus demografi'. Berdasarkan hasil kajian struktur umur penduduk berdasarkan hasil Sensus Penduduk tahun 2010 (disingkat SP 2010), terungkap bahwa secara nasional baru 12 propinsi yang berada pada era bonus demografi ( $\mathrm{DR}<50)$. Angka ketergantungan terendah diperoleh Provinsi DKI $(\mathrm{DR}=39,4)$. Capaian DR jauh dari angka 50 merupakan kesempatan emas (golden opportunity) mewujudkan kesejahteraan masyarakat yang lebih baik.

Propinsi Kalimantan Barat diperkirakan akan memasuki bonus demografi mulai tahun 2020 dengan angka DR = 49,7 persen hingga tahun 2035 dengan DR terendah 46,6 persen. Di antara 14 Kabupaten/Kota, hanya Kota Pontianak yang memperoleh bonus demografi pada tahun 2010 dengan angka DR $=47$ persen. Berdasarkan hasil proyeksi data SP 2010, ada dua dari 14 kabupaten/kota yang tidak mengalami era bonus demografi sepanjang siklus kependudukan, setidaknya hingga tahun 2035, yaitu Kabupaten Sambas dan Kabupaten Landak. Sementara itu, hanya Kabupaten Kapus Hulu yang capaian angka DR sebesar 43 persen membutuhkan waktu relatif cepat, yaitu tahun 2020. 
Jumlah penduduk Kabupaten Landak tahun 2010 sebanyak 329.649 jiwa (SP 2010). Penduduk yang masuk kategori usia muda dan usia lansia mencapai 119.019 jiwa atau 36,10\% dari total penduduk. Sementara jumlah penduduk usia kerja sekitar 210.630 jiwa atau 63,90\% dari jumlah penduduk keseluruhan. Adapun rasio ketergantungan di Kabupaten Landak sebesar 57 persen. Tingginya angka beban ketergantungan Kabupaten Landak tampak pada struktur usia penduduk yang menunjukkan relatif sedikitnya penduduk pada kelompok usia 30-39 tahun.

Tabel 1. Penduduk Menurut Kelompok Usia Non Produktif Dan Usia Produktif Di Kabupaten Landak, Tahun 2010-2035

\begin{tabular}{lcccccc}
\hline \multirow{2}{*}{ Uraian Komponen Utama } & SP & \multicolumn{5}{c}{ Proyeksi } \\
\cline { 3 - 7 } & $\mathbf{2 0 1 0}$ & $\mathbf{2 0 1 5}$ & $\mathbf{2 0 2 0}$ & $\mathbf{2 0 2 5}$ & $\mathbf{2 0 3 0}$ & $\mathbf{2 0 3 5}$ \\
\hline Jumlah Penduduk & 329.649 & 363.707 & 389.442 & 433.444 & 465.452 & 492.929 \\
- Penduduk Usia $<15$ tahun & 108.658 & 110.435 & 113.969 & 124.382 & 124.956 & 121.045 \\
- Penduduk Usia $>$ 64 tahun & 10.361 & 12.434 & 16.200 & 22.242 & 29.053 & 37.078 \\
- Penduduk Usia 15-64 tahun & 210.630 & 239.402 & 266.207 & 283.631 & 306.932 & 328.557 \\
\hline \multicolumn{1}{c}{ Dependency Ratio (DR) } & $\mathbf{5 7}$ & $\mathbf{5 2}$ & $\mathbf{5 0}$ & $\mathbf{5 3}$ & $\mathbf{5 2}$ & $\mathbf{5 0}$ \\
\hline
\end{tabular}

Sumber: BPS (2010)

Meski terjadi penurunan rasio ketergantungan sepanjang periode 2015-2035, namun berdasarkan perhitungan proyeksi penduduk dalam rentang waktu 2015-2035 menunjukkan Kabupaten Landak tidak memperoleh bonus demografi. Rasio ketergantungan sampai tahun 2035 tetap masih tinggi yakni 50 persen (lihat Tabel 1).

Rasio ketergantungan yang masih tetap tinggi sampai tahun 2035 menunjukkan bahwa penduduk usia $<15$ tahun di Kabupaten Landak masih cukup besar, demikian pula halnya dengan penduduk menua yang jumlahnya juga terus meningkat. Oleh karenanya menarik untuk diteliti mengapa bonus demografi di Kabupaten Landak tidak tercapai di periode 2035.

\section{KAJIAN LITERATUR}

Shryock \& Jacob (1976) membagi pengertian demografi dalam dua pengertian, yaitu (1) dalam arti sempit disebut formal demography yang penekanannya pada masalah jumlah, distribusi, struktur dan pertumbuhan penduduk, dan (2) dalam arti luas, demografi mencakup semua karakteristik penduduk, termasuk budaya, sosial, politik dan ekonomi. Terkait dengan pengertian ini, analisis aspek kependudukan dalam pembangunan menyangkut tentang bagaimana dampak ekonomi yang ditimbulkan dari dinamika penduduk. Pengertian dinamika penduduk sendiri mencakup perubahan jumlah, struktur dan persebaran penduduk yang diakibatkan oleh variabel fertilitas, mobilitas dan mortalitas. Perubahan dalam dinamika penduduk dapat dicermati berdasarkan transisi demografi yang dialami oleh berbagai negara. 
Salah satu fenomena demografi yang tidak terelakkan adalah pertumbuhan penduduk. Pertumbuhan penduduk menunjukkan penambahan jumlah penduduk karena kelahiran maupun migrasi. Penduduk yang semakin bertambah berpeluang menjadi sebuah potensi bagi suatu negara. Hal ini karena pertumbuhan penduduk ditinjau bukan hanya dari segi penambahan, tetapi dari perubahan struktur umur penduduk. Perubahan struktur umur penduduk merupakan hasil dari terjadinya transisi demografi, sedangkan pertumbuhan penduduk merupakan salah satu faktor yang mempercepat terjadinya transisi demografi. Hubungan ini diungkapkan oleh International Conference on Population and Development's (ICPD) 1994 di Kairo Mesir yang berpendapat bahwa penduduk memiliki dampak positif pada pertumbuhan ekonomi dan mendukung percepatan transisi demografi (Kuncoro \& Sonny, 2016).

\subsection{Teori Transisi Demografi}

Teori transisi demografi berkembang di Eropa, pada abad ke-18, ditandai dengan penurunan angka kelahiran dan kematian yang terjadi secara terus-menerus (Lucas, 1987; Mantra, 1994; Todaro dan Stephen, 2011). Namun pada waktu itu, belum ada data yang dapat menjelaskan mengapa transisi demografi terjadi. Umumnya, para peneliti mengatakan hal tersebut disebabkan karena adanya revolusi industri yang mengubah perilaku orang tua - mazhab keluarga besar menjadi keluarga kecil.

Berbeda dengan transisi demografi yang dialami Indonesia. Di Indonesia, transisi demografi yang terjadi karena program keluarga berencana (KB) pada era 1970-an hingga 1990-an sangat masif dikerjakan (Adioetomo \& Omas, 2011). Program KB mampu mengubah pola pikir orang tua ke arah untuk membangun keluarga kecil dengan dua (atau setidaknya tiga) anak saja.

Proses transisi demografi pertumbuhan penduduk dipengaruhi oleh beberapa faktor, yaitu faktor alamiah dan faktor dari luar. Faktor alamiah terjadinya perubahan jumlah penduduk adalah kelahiran (fertilitas) dan kematian (mortalitas). Sementara itu, faktor-faktor lain yang mungkin memengaruhi laju pertumbuhan penduduk adalah faktor yang berasal dari luar, seperti perpindahan penduduk (mobilitas), pertumbuhan ekonomi, gaya hidup, bencana alam, dan lain-lain.

Blacker (1947) berpendapat bahwa transisi demografi terbagi menjadi lima tahap, yaitu (a) high stationary, (b) early expanding, (c) late expanding, (d) low stationary, (e) declining. Tahapan satu terjadi pada masyarakat pra-industri dengan tingkat fertilitas dan tingkat mortalitas yang tinggi. Tahapan kedua menunjukkan penurunan tingkat mortalitas pelan dan peningkatan populasi cepat. Tahapan tiga menunjukkan tingkat mortalitas yang turun dengan cepat dan diikuti penurunan tingkat fertilitas, tetapi tidak secepat penurunan tingkat mortalitas. Tahapan empat terjadi ketika kelahiran dan angka kematian rendah atau nol. Oleh karena itu, jumlah penduduk relatif tinggi dan stabil, dan 
tahap kelima, tingkat mortalitas lebih tinggi dibandingkan dengan tingkat fertilitas yang berada dalam keadaan stabil.

\subsection{Bonus Demografi}

Bonus demografi dapat terjadi ketika pertumbuhan penduduk usia kerja lebih tinggi dibandingkan penduduk usia muda. Adanya transisi demografi memungkinkan terjadinya penurunan proporsi penduduk muda dan meningkatnya proporsi penduduk usia kerja. Mason (2001) dan Ross (2004) berpendapat bahwa penurunan proporsi penduduk muda dapat memperkecil rasio ketergantungan dengan cara berkurangnya besaran investasi untuk pemenuhan kebutuhan sehingga sumber daya dapat dialihkan untuk investasi yang mendorong pertumbuhan ekonomi dan peningkatan kesejahteraan keluarga. Meskipun begitu, masih ada hal lain yang perlu dilakukan untuk dapat memanfaatkan bonus demografi tersebut.

Bonus demografi memberikan suatu kesempatan (jendela peluang-window of opportunity) yang hanya terjadi satu kali berupa tersedianya kondisi atau ukuran yang sangat ideal antara jumlah penduduk produktif dan non-produktif (Ananta dan Arifin, 2009). Rasio ketergantungan penduduk akan berada pada titik terendah, biasanya di bawah 50 persen. Window of opportunity ini, menurut Khalifa (2009) hanya akan berlangsung satu atau dua dekade saja karena adanya peningkatan harapan hidup menyebabkan meningkatnya proporsi penduduk usia lansia (64 tahun ke atas) sehingga harus dapat dimanfaatkan dengan maksimal.

Bongaarts (2001) dan Bloom et al (2003) mengungkapkan beberapa hal yang mampu menjelaskan hubungan antara bonus demografi dan pertumbuhan ekonomi. Hal tersebut adalah penawaran tenaga kerja (labor supply), peranan perempuan, tabungan (saving), dan modal manusia (human capital).

Dalam hal penawaran tenaga kerja, setidaknya ada dua faktor yang mempengaruhi, yaitu generasi baby boom dan penurunan fertilitas. Dengan penurunan tingkat kematian, kohor baby boom tersebut semakin lama akan tumbuh hingga mencapai usia kerja. Sementara itu, penurunan fertilitas yang diikuti penurunan kematian bayi juga akan meningkatkan proporsi penduduk usia kerja sehingga proporsinya lebih tinggi dibanding penduduk muda. Jika tenaga kerja yang melimpah ini mampu terserap dalam lapangan pekerjaan yang baik (decent work) maka produksi per kapita akan meningkat sehingga pertumbuhan ekonomi pun juga ikut naik dan bahkan mencapai level tertingginya.

Melimpahnya jumlah tenaga kerja diyakini mampu meningkatkan tabungan \{saving). Dalam struktur perekonomian, peningkatan tabungan akan meningkatkan gross domestic product (GDP — atau dikenal juga sebagai produk domestik bruto (PDB). Dalam age-dependency model, penurunan kelahiran, akan menurunkan konsumsi dan beralih pada peningkatan tabungan yang dapat digunakan untuk pembentukan modal (capital) 
(Jong-Il, K. dan L.J. Lau, 1996). Kalau tabungan ini diinvestasikan ke sektor produktif, menurut Bongaarts (2001), akan meningkatkan pertumbuhan ekonomi. Pertumbuhan ekonomi tinggi idealnya diikuti penurunan angka kemiskinan dan pengangguran.

Adanya transisi demografi, yang ditandai dengan penurunan kematian seiring dengan kemajuan kehidupan sosial ekonomi masyarakat disertai dengan peningkatan angka harapan hidup, telah mengubah perilaku dan paradigm masyarakat. Angka harapan hidup yang tinggi membuat penduduk memiliki waktu yang cukup banyak untuk berproduksi dan berinvestasi. Terjadi perubahan paradigma, jika pada awalnya manusia dianggap sebagai faktor produksi, kini berubah menjadi manusia sebagai aset.

Apabila ditinjau keterkaitan transisi demografi dengan struktur usia penduduk, Adioetomo dan Omas (2011) menjelaskan bahwa penurunan fertilitas akan menurunkan proporsi jumlah anak yang berusia kurang dari 15 tahun. Selain itu, selama masa transisi, angka kematian bayi mengalami penurunan yang cukup drastis sehingga meningkatkan jumlah bayi yang tetap hidup hingga ke usia dewasa. Akibatnya, terjadilah ledakan penduduk usia kerja.

\subsection{Bonus Demografi dan Pertumbuhan Ekonomi}

Todaro (2011) menjelaskan bahwa pertumbuhan penduduk pada akhirnya meningkatkan jumlah angkatan kerja. Jumlah tenaga kerja yang besar akan menambah jumlah tenaga produktif. Positif atau negatifnya dampak pertambahan penduduk dan tenaga kerja bagi pembangunan ekonomi tergantung pada kemampuan sistem perekonomian yang bersangkutan untuk menyerap dan secara produktif memanfaatkan tambahan tenaga kerja tersebut.

Hubungan bonus demografi, pertumbuhan penduduk, dan pertumbuhan ekonomi adalah suatu keadaan dimana pertumbuhan penduduk usia muda mengalami penurunan dan pada keadaan ini pertumbuhan penduduk usia kerja mengalami peningkatan sehingga pertumbuhan ekonomi lebih dapat tercapai karena pada saat bonus demografi inilah tanggungan pada kebutuhan usia muda rendah. Adioetomo (2010) mengungkapkan bahwa penurunan proporsi penduduk muda mengurangi besarnya biaya investasi untuk pemenuhan kebutuhannya, sehingga sumber daya dapat dialihkan untuk memacu pertumbuhan ekonomi dan peningkatan kesejahteraan keluarga.

Lebih lanjut Adioetomo (2010) menjelaskan keadaan bonus demografi meledaknya penduduk usia kerja dapat menguntungkan pertumbuhan ekonomi melalui empat hal. Pertama, suplai tenaga kerja yang besar meningkatkan pendapatan per kapita apabila mendapat kesempatan kerja yang produktif. Kedua, melalui peran perempuan. Jumlah anak sedikit memungkinkan perempuan memasuki pasar kerja sehingga membantu peningkatan pendapatan. Ketiga, tabungan masyarakat yang diinvestasikan secara produktif. Keempat, modal manusia yang besar apabila terdapat investasi untuk itu. 
Bloom (2003), menjelaskan bahwa ketika jumlah penduduk usia kerja dalam populasi lebih besar daripada jumlah penduduk tua dan muda, maka akan ada jendela peluang di mana produktivitas penduduk usia kerja dan tingkat konsumsi dapat meningkat dan perekonomian bisa mendapat keuntungan. Dampak kombinasi dari bonus demografi dan kebijakan yang efektif pada area-area lain dapat menstimulasi pertumbuhan ekonomi. Manusia-manusia produktif lebih berpendidikan, sehat, mobilitas lebih tinggi dan memiliki aspirasi yang lebih tinggi dari kohor sebelumnya.

Periode yang dicirikan oleh rendahnya angka ketergantungan akan dicirikan pula oleh pertumbuhan yang lebih tinggi, jika tersedia pancingan untuk menginvestasikannya. Jika jendela peluang tersedia ketika tambahan penduduk memasuki kelompok usia kerja, akan tercipta akselerasi dalam pertumbuhan. Proses pembangunan harus menjamin bahwa kualitas penduduk yang memasuki usia kerja adalah pada tingkat yang diinginkan dan pekerja tersebut menemukan kesempatan kerja.(Chandrasekhar, et al, 2006).

Bloom \& Canning (2004) dalam Chandrasekhar, et al (2006) mengungkapkan bahwa secara empiris dan teoritis, tidak ada hubungan yang otomatis antara perubahan demografi dengan pertumbuhan ekonomi. Perubahan distribusi umur hanya membentuk suatu potensi bagi pertumbuhan ekonomi. Ditangkap atau tidaknya potensi ini tergantung pada kebijakan setempat. Hal ini juga menunjukkan bahwa transisi demografis dimana rasio ketergantungan menjadi kecil tidak secara langsung mengakibatkan meningkatnya pertumbuhan ekonomi. Bila potensi ini tidak dimanfaatkan maka sebaliknya yang akan terjadi adalah meningkatnya pengangguran yang akan berdampak pada keadaan sosial dan ekonomi masyarakat.

Namun demikian, terdapat pula peneliti yang menunjukkan bahwa peran modal manusia tidak terlalu besar dalam penciptaan pertumbuhan. Nelson \& Phelps (1966) dalam Diliberto, Pigliaru \& Chelucci (2008) menghasilkan sebuah pendekatan yang menunjukkan peran langsung modal manusia dalam pertumbuhan hanya kecil. Modal manusia menentukan sejauh mana sebuah Negara yang tertinggal dapat mengekstrak kelebihan teknologi (mengadopsi) dari negara maju. Meskipun modal manusia memiliki peran langsung yang kecil, namun perannya sebagai penentu perkembangan teknologi sangat besar dan secara tidak langsung juga menunjukkan peran besarnya terhadap pertumbuhan ekonomi.

\section{METODA PENELITIAN}

Data yang dikumpulkan dalam penelitian ini adalah data sekunder, yang diperoleh dari publikasi/dokumen instansi pemerintah antara lain: BPS Provinsi Kalimantan Barat, BPS Kabupaten Landak, Dinas Kesehatan dan KB Kabupaten Landak dan Bappeda Kabupaten Landak. Pengumpulan data diperoleh dari publikasi/dokumen (desk study) seperti: Sensus Penduduk 2010 Kalimantan Barat, Kabupaten Landak Dalam Angka, 
Survey Angkatan Kerja Nasional, Statistik Daerah Kabupaten Landak, Profil Kesehatan Kabupaten Landak, dan Profil Pendidikan Di Kabupaten Landak.

Untuk kepentingan kajian, mengacu pada data pokok Sensus Penduduk Tahun 2010 yang diperoleh dari BPS kemudian dilakukan proses pengolahan data lanjutan untuk kebutuhan proyeksi. Alat analisis yang digunakan adalah Program Spectum sebagai policy model untuk memberikan informasi mengenai suatu dampak pembangunan dimasa yang akan datang berdasarkan informasi dari pembangunan saat ini.

\section{HASIL PENELITIAN DAN PEMBAHASAN}

Sebagaimana telah dipaparkan pada pendahuluan, rasio ketergantungan (RK) merupakan perbandingan antara jumlah penduduk non produktif dengan jumlah penduduk produktif. Penduduk usia non produktif meliputi penduduk usia 0-14 tahun dan usia 65 tahun ke atas, sedangkan penduduk usia produktif adalah penduduk usia kerja 15-64 tahun. Berdasarkan formulasi ini dapat dinyatakan bahwa tinggi rendahnya RK sangat dipengaruhi oleh besar kecilnya pertumbuhan pada masing-masing kelompok umur non produktif dan produktif.

Sebelum suatu Negara/daerah mencapai RK di bawah 50 (belum mencapai bonus demografi), peningkatan RK mula-mula lebih disebabkan proporsi pertambahan penduduk usia 0-14 tahun lebih besar dari proporsi pertambahan penduduk usia 65 tahun ke atas, kemudian dalam jangka panjang - sebagai akibat penurunan TFR - peningkatan RK ditandai dengan meningkatnya proporsi penduduk usia 65 tahun ke atas.

Perubahan jumlah penduduk pada setiap kelompok umur berkaitan erat dengan variable fertilitas, mortalitas dan migrasi. Ketiga variabel ini menjadi acuan dalam menganalisis belum tercapaianya bonus demografi pada saat kabupaten/kota lainnya sudah mencapai bonus demografi.

\subsection{Aspek Fertilitas}

Tingkat fertilitas sangat berpengaruh pada struktur umur penduduk. Struktur umur penduduk saat ini merupakan hasil kelahiran, kematian dan migrasi masa lalu. Sebaliknya, struktur umur penduduk saat ini akan menentukan perkembangan penduduk di masa yang akan datang. Jika tingkat fertilitas tinggi, tingkat kematian rendah dan migrasi bersih nol, maka struktur umur penduduk berkonsentrasi pada umur muda (kurang dari 10 tahun).

Kabupaten Landak tergolong pada penduduk berstruktur umur muda. Ini terbukti dari jumlah penduduk usia $<15$ tahun $(32,96 \%)$ jauh lebih banyak dibanding jumlah penduduk usia $<64$ tahun $(3,14 \%)$. Penduduk usia 15-64 tahun $=63,90 \%$ dari 329.649 jiwa penduduk Kabupaten Landak. 
$\mathrm{DR}_{\text {total }}$ sebesar 57 persen ini disumbangkan oleh RK penduduk muda sebesar 52 persen, dan DR penduduk tua sebesar 5 persen. Kondisi ini bermakna bahwa pada tahun 2010 penduduk usia kerja di Kabupaten Landak masih dibebani tanggung jawab akan penduduk muda yang proporsinya lebih banyak dibandingkan tanggung jawab terhadap penduduk tua. Daerah yang tergolong berstruktur umur muda berpotensi untuk mendorong tingginya angka fertilitas. Selain itu, karakteristik penduduk muda akan mempunyai beban besar dalam investasi sosial untuk pemenuhan kebutuhan pelayanan dasar bagi anak-anak kurang dari 15 tahun ini, membangun sarana dan prasarana pelayanan dasar (pendidikan dan kesehatan)

Hasil Sensus Penduduk (SP) 2010 menunjukkan TFR Kabupaten Landak sebesar 2,48. Ini berarti setiap wanita di Kabupaten Landak pada tahun 2010 rata-rata mempunyai anak sebanyak 3 di akhir masa reproduksinya. Capaian ini tergolong tinggi. Secara spesifik berdasarkan kelompok umur, peristiwa kelahiran terbanyak terjadi pada kelompok umur 25-29 tahun. Puncak ASFR terletak pada kelompok umur 25-29 dengan jumlah kelahiran hidup sebanyak 134 per 1000 perempuan (lihat Tabel 2). Hal ini mengindikasikan bahwa anjuran pemerintah untuk "tidak melahirkan pada usia yang terlalu muda" sudah mencapai sasaran. Fenomena ini bisa dikaitkan dengan suksesnya program wajib belajar sembilan tahun yang menyebabkan semakin banyaknya perempuan muda yang bersekolah lebih tinggi, dan semakin terbukanya kesempatan bagi perempuan di pasar kerja.

TFR yang tinggi berpengaruh pada peningkatan RK karena akan menambah jumlah penduduk usia belum produktif (0-14 tahun). TFR yang tinggi merupakan cerminan rata-rata usia kawin yang rendah (usia muda), tingkat pendidikan rendah terutama perempuannya, tingkat sosial ekonomi rendah atau tingkat kemiskinan yang tinggi.

Tabel 2. ASFR dan TFR Kabupaten Landak dan Kalimantan Barat (Hasil SP 2010)

\begin{tabular}{lcccccccc}
\hline \multirow{2}{*}{ Daerah } & $\mathbf{1 5 - 1 9}$ & $\mathbf{2 0 - 2 4}$ & $\mathbf{2 5 - 2 9}$ & $\mathbf{3 0} \mathbf{- 3 4}$ & $\mathbf{3 5}-\mathbf{3 9}$ & $\mathbf{4 0}-\mathbf{4 4}$ & $\mathbf{4 5}-\mathbf{4 9}$ & \multirow{2}{*}{ TFR } \\
\cline { 2 - 8 } & 36 & 131 & 134 & 98 & 62 & 27 & 8 & 2.48 \\
Kab. Landak & 42 & 131 & 142 & 110 & 70 & 28 & 10 & 2.66 \\
Kalbar & 42 &
\end{tabular}

Sumber: BPS Propinsi Kalimantan Barat (2011)

Meskipun menurut Pasal 7 ayat 1 UU No.1 tahun 1974 bahwa usia minimal menikah bagi laki-laki 19 tahun dan perempuan 16 tahun, namun kenyataannya di Kabupaten Landak terdapat umur kawin pertama antara 10-14 tahun dan segera memiliki anak lahir hidup (ALH), lihat Tabel 3. Makin muda usia seseorang melakukan pernikahan, makin panjang masa reproduksinya, dan makin banyak anak yang dilahirkan. Hubungan antara usia perkawinan dengan fertilitas adalah negatif.

Hasil SP 2010 memperlihatkan bahwa dari 2.015.975 jiwa penduduk Kalimantan Barat yang berstatus kawin, terdapat 2.892 jiwa menikah pada usia 10-14 tahun, cerai 
hidup sebanyak 110 jiwa dan cerai mati sebanyak 153 jiwa. Selanjutnya, yang menikah pada usia 15-19 tahun sebanyak 37.369 jiwa, cerai hidup 1.124 jiwa dan cerai mati sebanyak 204 jiwa.

Tabel 3. Jumlah Anak Lahir Hidup (ALH) Berdasarkan Kelompok Umur Wanita Pernah Kawin

\begin{tabular}{|c|c|c|c|c|c|c|c|c|c|c|}
\hline \multirow{3}{*}{ Daerah } & \multicolumn{9}{|c|}{ Umur wanita pernah kawin } & \multirow{3}{*}{$\begin{array}{c}\text { Jlh } \\
\text { ALH }\end{array}$} \\
\hline & 10-14 & 15-19 & 20-24 & $25-29$ & 30-34 & 35-39 & $40-44$ & $45-49$ & $50-54$ & \\
\hline & ALH & ALH & ALH & ALH & ALH & ALH & ALH & ALH & ALH & \\
\hline Perk & 1.200 & 0.824 & 1.129 & 1.616 & 2.207 & 2.756 & 3.218 & 3.492 & 3.767 & 2.400 \\
\hline Pedesaa & 0.657 & 0.769 & 1.241 & 1.859 & 2.675 & 3.393 & 3.817 & 3.982 & 4.035 & 2.807 \\
\hline $\mathrm{K}+\mathrm{D}$ & 0.685 & 0.772 & 1.233 & 1.836 & 2.635 & 3.338 & 3.771 & 3.944 & 4.015 & 2.774 \\
\hline
\end{tabular}

Sumber: BPS (2011)

Bila ditelusuri lebih jauh, tampak bahwa jumlah perempuan yang menikah lebih banyak dibanding laki-laki, baik di kota maupun di desa. Tidak hanya itu, penduduk perempuan yang berstatus cerai hidup dan cerai mati juga lebih banyak dibanding lakilaki, baik di kota maupun di desa (lihat Tabel 4).

Data pada Tabel 3 dan Tabel 4 menginformasikan bahwa perkawinan usia dini dan fertilitas di usia muda berkaitan erat. Semakin lama masa perkawinan maka akan semakin panjang kemungkinan untuk melahirkan yang nantinya dapat berdampak terhadap tingginya fertilitas.

Tabel 4 Jumlah Penduduk Berdasarkan Status Perkawinan di Kabupaten Landak Tahun 2010

\begin{tabular}{lcccccc}
\hline \multirow{2}{*}{$\begin{array}{c}\text { Status } \\
\text { Perkawinan }\end{array}$} & \multicolumn{2}{c}{ Kota } & \multicolumn{2}{c}{ Desa } & \multicolumn{2}{c}{ Kota + Desa } \\
\cline { 2 - 7 } & Laki-laki & Perempuan & Laki-laki & Perempuan & Laki-laki & Perempuan \\
\hline Belum Kawin & 4.907 & 4.349 & 55.262 & 37.234 & 60.169 & $41 . .583$ \\
Kawin & 5.723 & 5.782 & 65.747 & 65.967 & 71.470 & 71.749 \\
Cerai Hidup & 37 & 134 & 836 & 1.382 & 873 & 1.516 \\
Cerai Mati & 14 & 574 & 3.414 & 7.635 & 3.428 & 8.209 \\
\hline Jumlah & 10,681 & 10,839 & 125,259 & 112.218 & 135.940 & 123.057 \\
\hline
\end{tabular}

Sumber: BPS (2011)

\subsection{Faktor Pendorong Pernikahan Dini dan Fertilitas Usia Muda}

Menurut Suparyanto (2009) yang dikutip oleh Direktorat Pemaduan Kebijakan Pengendalian Penduduk (2010) terdapat dua faktor penyebab terjadinya pernikahan dini, yaitu sebab dari anak dan dari luar anak. Kedua penyebab ini terungkap juga dalam Focus Group Discussion (FGD) yang dilakukan pada tanggal 20 Mei 2015 di Gedung Pertemuan Dinas Pemberdayaan Perempuan dan KB Kabupaten Landak. Penyebab terjadinya pernikahan dini yang bersumber dari Anak meliputi faktor pendidikan, faktor melakukan hubungan biologis dan faktor hamil sebelum nikah. 
Jika seorang anak putus sekolah pada usia wajib sekolah, kemudian mengisi waktu dengan bekerja, maka anak tersebut sudah merasa cukup mandiri dan mampu menghidupi diri sendiri. Sebaliknya, jika anak yang putus sekolah tersebut menganggur. Dalam kekosongan waktu tanpa pekerjaan membuat mereka akhirnya melakukan hal-hal yang tidak produktif. Salah satunya adalah menjalin hubungan dengan lawan jenis, yang jika di luar control, membuat kehamilan luar nikah. Faktor tingkat pendidikan juga berdampak pada pemanfaatan handphone, internet kepada tontonan pornografi yang berujung pada pergaulan bebas. Hal ini terungkap dalam FGD berdasarkan pengamatan seorang pelajar SMA yang tergabung dalam PIK Remaja Kabupaten Landak.

Selain itu, pada beberapa kasus pernikahan dini timbul karena anak-anak telah melakukan hubungan biologis layaknya suami istri. Dengan kondisi seperti ini, orangtua anak perempuan cenderung segera menikahkan anaknya karena menurut orangtua anak perempuan apabila sudah tidak perawan lagi akan menjadi aib bagi keluarga. Keadaan ini dikenal dengan sebutan married by accident.

Jika kondisi anak perempuan itu dalam keadaan hamil, maka orangtua cenderung menikahkan anak-anak tersebut. Bahkan ada bebarapa kasus, walau pada dasarnya orangtua anak gadis ini tidak setuju dengan calon menantunya, tapi karena kondisi kehamilan, maka dengan terpaksa orangtua menikahkan anak gadis tersebut. Keadaan ini termasuk married by accident.

Selain penyebab yang berasal dari anak, penyebab terjadinya pernikahan dini juga bersumber dari luar Anak, yang meliputi faktor pemahaman agama, faktor ekonomi, serta faktor adat dan budaya. Salah satu contoh kasus mengenai faktor pemahaman agama adalah dimana orang tua anak menyatakan bahwa anak menjalin hubungan biologis dengan lawan jenis merupakan "perzinahan". Untuk mencegah hal tersebut, orangtua segera menikahkan anaknya.

Ada beberapa kasus timbul akibat faktor ekonomi dimana orang tua terlilit hutang dan tidak mampu membayar. Jika si orang tua yang terlilit hutang tadi mempunyai anak gadis usia muda, maka anak gadis tersebut diserahkan sebagai "alat pembayaran" kepada si piutang. Setelah anak tersebut dikawini, maka lunaslah hutang-hutang yang melilit orang tua si anak.

Di beberapa daerah, terdapat beberapa pemahaman tentang perjodohan. Seorang anak gadis, sejak kecil telah dijodohkan orangtuanya dan akan segera dinikahkan sesaat setelah anak tersebut mengalami masa menstruasi. Umumnya anak-anak perempuan mulai menstruasi pada usia 12 tahun. Sehingga besar kemungkinan si anak gadis dinikahkan pada usia muda. 


\subsection{Perkembangan PUS dan KB}

Pemerintah c.q. Badan Pemberdayaan Perempuan dan Keluarga Berencana (BPPKB) Kabupaten Landak aktif menjalankan Program Keluarga Berencana untuk menurunkan TFR. Program KB di Kabupaten Landak berjalan lancar dan telah memasyarakat di seluruh kecamatan. Jumlah Pasangan Usia Subur (PUS) bertambah setiap tahun dan tahun 2013 tercatat sebanyak 66.341 pasangan tersebar di seluruh kecamatan. PUS terbanyak berada di Kecamatan Ngabang (14.065 pasangan) dan terendah di Kecamatan Meranti (1.870 pasangan). Capaian persentase PA/PUS tertinggi $(99,04 \%)$ terdapat di Kecamatan Sebangki dengan jumlah PUS sebanyak 2.818 pasangan sedangakan PA/PUS terendah $(52,10)$ ada di Kecamatan Sompak dengan jumlah PUS sebanyak 2.449 pasangan.

Peserta KB Aktif yang menggunakan metode kontrasepsi semakin meningkat. PA/PUS tahun $2010=67 \%$, kemudian meningkat terus setiap tahunnya hingga mencapai 72,58\% tahun 2013. Ini berarti dari 100 PUS, 73 pasangan diantaranya menggunakan kontrasepsi. Hal yang berbeda terjadi pada peserta KB Baru dimana persentase PA/PUS nya melebihi 100, tepatnya $119,87 \%$ tahun 2013. Peningkatan peserta KB Aktif dan KB Baru tidak serta merta menurunkan tingkat kelahiran. Bisa terjadi PUS aktif menggunakan alat kontrasepsi setelah usia mendekati menopause atau setelah punya anak lebih dari dua.

Bersamaan dengan capaian di atas, Peserta KB Lestari bertambah setiap tahunnya, baik peserta KB Lestari 5 tahun, 10 tahun dan 16 tahun. Hingga tahun 2013 peserta KB Lestari 5 tahun sebanyak 5.118 ; KB Lestari 10 tahun sebanyak 3.039 dan KB Lestari 16 tahun sebanyak 1.617. Peserta KB Lestari terbanyak berada di Kecamatan Ngabang dan terendah berada di Kecamatan Jelimpo.

\subsection{Aspek Mortalitas}

Mortalitas atau kematian dapat menimpa siapa saja, tua, muda, kapan dan dimana saja. Kasus kematian terutama dalam jumlah banyak berkaitan dengan masalah sosial, ekonomi, adat istiadat maupun masalah kesehatan lingkungan. Peristiwa tsunami, banjir bandang, longsor, konflik sosial antar suku/etnis, kecelakaan pesawat/kereta api/bis/kapal laut merupakan contoh yang mengakibatkan kasus kematian dalam jumlah besar. Indikator kematian berguna untuk memonitor kinerja pemerintah pusat maupun lokal dalam peningkatan kesejahteraan masyarakat.

Kematian dewasa umumnya disebabkan karena penyakit menular, penyakit degeneratif, kecelakaan atau gaya hidup yang beresiko terhadap kematian. Kematian bayi dan balita umumnya disebabkan oleh penyakit sistim pernapasan bagian atas (ISPA) dan diare, yang merupakan penyakit karena infeksi kuman. Faktor gizi buruk juga menyebabkan anak-anak rentan terhadap penyakit menular, sehingga mudah terinfeksi dan menyebabkan tingginya kematian bayi dan balita di sesuatu daerah. 
Faktor sosial ekonomi seperti pengetahuan tentang kesehatan, gizi dan kesehatan lingkungan, kepercayaan, nilai-nilai, dan kemiskinan merupakan faktor individu dan keluarga, mempengaruhi mortalitas dalam masyarakat (Utomo \& Tara, 2011). Tingginya kematian ibu merupakan cerminan dari ketidak tahuan masyarakat mengenai pentingnya perawatan ibu hamil dan pencegahan terjadinya komplikasi kehamilan.

Berdasarkan hasil SP 2010, tingkat kematian kasar (Crude Death Rate/CDR) di Kabupaten Landak relatif rendah, masih di bawah rata-rata Kalimantan Barat. CDR Kabupaten Landak sebesar 2,5 per 1000 penduduk merupakan yang terendah di Kalimantan Barat (CDR Kalbar = 3,2 per 1000 penduduk). Berdasarkan kelompok umur, peristiwa kematian terjadi dengan pola huruf $U$, artinya pada kelompok umum 0-4 tahun jumlah kematian relatif banyak, kemudian menurun hingga pada kelompok umur 45-49 tahun lalu meningkat terus hingga kelompok umur 75+ tahun.

Angka kematian bayi (IMR) di Kabupaten Landak juga merupakan yang terendah di Kalimantan Barat, yakni 21 per 1000 kelahiran hidup. Ini berarti diantara 1000 kelahiran hidup ada 21 bayi yang meninggal sebelum usia tepat 1 tahun. Secara teoritis, perkembangan IMR asimetris (berlawanan) dengan Usia Harapan Hidup (UHH) saat lahir. Jika IMR semakin rendah, maka UHH semakin tinggi dan sebaliknya. UHH tertinggi (72,53 tahun) terdapat di Kabupaten Bengkayang dengan IMR sebesar 21 per 1000 kelahiran hidup. UHH Kabupaten Landak sebesar 71,80 tahun dengan IMR sebesar 21 per 1000 kelahiran hidup.

Angka Kematian Ibu (MMR) di Kabupaten Landak sebesar 232 per 100.000 kelahiran hidup. Angka ini masih tergolong tinggi dibandingkan MMR Kabupaten Kubu Raya (121 per 100.000 kelahiran hidup, lihat Tabel 2. Tingginya angka kematian ibu merupakan cerminan dari ketidak tahuan masyarakat mengenai pentingnya perawatan ibu hamil dan pencegahan terjadinya komplikasi kehamilan.

Pernikahan dini dan fertilitas usia muda berkontribusi terhadap tingginya angka kematian ibu. Menurut hasil penelitian organisasi kesehatan dunia (WHO) tahun 2014 bahwa kehamilan remaja menjadi penyumbang terbesar terhadap AKI (MMR) dan AKB (IMR). Secara global komplikasi kehamilan dan persalinan adalah penyebab kematian kedua terbesar pada wanita usia 15-19 tahun. Hampir 3 juta remaja usia 15-19 tahun melakukan aborsi tidak aman. Selain mengancam si Ibu, kehamilan remaja juga mengancam kesehatan bayi. Bayi yang dilahirkan si Ibu usia kurang dari 20 tahun memiliki resiko kematian lebih tinggi dibanding kelahiran usia lebih dari 20 tahun. Pada saat kehamilan resiko kematian remaja dua kali lebih besar daripada kehamilan normal. Penyebabnya, saat persalinan kemungkinan terjadi pendarahan, kerusakan janin dan kecacatan bayi (MEDIA INDONESIA, 24 Juni 2015).

Angka kematian yang rendah berpengaruh ternadap peningkatan rasio ketergantungan (RK). Dengan demikian, rendahnya CDR, IMR dan MMR di Kabupaten Landak berpengaruh terhadap tinggnya RK. 


\subsection{Aspek Migrasi}

Secara ekonomi, Kabupaten Landak merupakan salah satu daerah pilihan untuk berinvestasi, terutama di sub sektor perkebunan dan pertambangan. Investasi pada perkebunan kelapa sawit sudah lama berlangsung (sekitar 30 tahun). Perkebunan dengan pola PIR-Trans mengundang banyak jiwa yang datang ke Kabupaten Landak (inmigration). Pada saat yang sama ada penduduk Kabupaten Landak (terutama usia muda) keluar menuju daerah lain dengan berbagai alasan (misalnya untuk melanjutkan studi). Ini yang disebut migrasi keluar (out migration).

Tabel 4. Migrasi Risen Kabupaten Landak Berdasarkan SP Tahun 2010

\begin{tabular}{cccc}
\hline $\begin{array}{c}\text { Kelompok Umur } \\
\text { (tahun) }\end{array}$ & $\begin{array}{c}\text { Masuk } \\
\text { (jiwa) }\end{array}$ & $\begin{array}{c}\text { Keluar } \\
\text { (jiwa) }\end{array}$ & $\begin{array}{c}\text { Net Migrasi } \\
\text { (jiwa) }\end{array}$ \\
\hline $5-9$ & 298 & 452 & -154 \\
$10-14$ & 326 & 442 & -116 \\
$15-19$ & 401 & 1.495 & -1.094 \\
$20-24$ & 542 & 2.105 & -1.563 \\
$25-29$ & 551 & 935 & -384 \\
$30-34$ & 309 & 502 & -193 \\
$35-39$ & 210 & 322 & -112 \\
$40-44$ & 149 & 175 & -26 \\
4549 & 81 & 101 & -20 \\
$50-54$ & 54 & 88 & -34 \\
$55-59$ & 30 & 62 & -32 \\
$60-64$ & 21 & 36 & -15 \\
$65-69$ & 5 & 27 & -22 \\
$70-74$ & 6 & 21 & -15 \\
$75+$ & 9 & 24 & -15 \\
\hline Total & $\mathbf{2 . 9 9 2}$ & $\mathbf{6 . 7 8 7}$ & $\mathbf{- 3 . 7 9 5}$ \\
\hline
\end{tabular}

Sumber : BPS (2011)

Selisih migrasi masuk dengan migrasi keluar disebut migrasi bersih (Net Migration). Jika migrasi masuk lebih banyak dari migrasi keluar, itu berarti migrasi bersih adalah positip, berarti menambah jumlah penduduk. Namun jika migrasi masuk lebih sedikit dari migrasi keluar, itu berarti migrasi bersih adalah negatif, berarti mengurangi jumlah penduduk.

Hasil SP 2010 yang disajikan pada Tabel 4. mengundang tanda tanya, karena net migrasi pada setiap kelompok umur bertanda negatif. Artinya, jumlah migrasi masuk lebih banyak dari migrasi keluar, dan itu terjadi pada semua kelompok umur. Kejadian ini sudah barang tentu mengurangi jumlah penduduk Kabupaten Landak. Net Migrasi Kabupaten Landak sebanyak 3.795 jiwa. Net Migrasi terbanyak dilakukan oleh penduduk usia 20-24 tahun (1.563 jiwa). Banyaknya migrasi keluar oleh penduduk usia 20-24 tahun kemungkinan besar disebabkan keinginan mencari pekerjaan dan/atau melanjutkan studi ke Perguruan Tinggi di Pontianak dan/atau di luar Propinsi. 
Migran terbesar yang ke luar dari Kabupaten Landak adalah kelompok umur 1564 tahun $=3.473$ jiwa menyebabkan DR $=57$. Seandainya kelompok umur 15-64 tahun tidak migrasi keluar Kab. Landak, DR berkurang menjadi 56.

\section{KESIMPULAN}

Berdasarkan analisis yang telah dipaparkan, dapat disimpulkan bahwa penyebab belum tercapainya bonus demografi pada tahun 2010 berkaitan erat dengan masih tingginya kelahiran (Angka Kelahiran Total/TFR), relatif rendahnya Angka Kematian Kasar (CDR), Angka Kematian Bayi (IMR) dan Angka Kematian Ibu (MMR) serta Net Migrasi yang negatif. TFR yang relatif tinggi dipengaruhi adanya pernikahan dini dan fertilitas usia muda (10-19 tahun). Pernikahan Dini dan fertilitas usia muda beresiko meningkatkan IMR dan MMR.

Penelitian ini menggunakan data penduduk hasil SP 2010. Temuan dalam studi bonus demografi di Kabupaten Landak masih debatable. Oleh karena itu, perlu dikaji ulang oleh BPS, Perguruan Tinggi dan BKKBN penggunaan asumsi dalam penentuan waktu pencapaian bonus demografi. Tercapai atau tidak tercapai bonus demografi, Pemerintah Daerah wajib untuk meningkatkan kualitas sumberdaya manusia di masingmasing daerah.

\section{UCAPAN TERIMA KASIH}

Pada kesempatan ini, melalui tulisan ini disampaikan ucapan terima kasih kepada Kepala Kantor Perwakilan BKKBN Propinsi Kalimantan Barat yang membiayai penelitian ini. Juga ucapan yang sama disampaikan kepada pihak Kantor Pemberdayaan Perempuan dan KB Kabupaten Landak yang memfasilitasi pelaksanaan FGD.

\section{DAFTAR PUSTAKA}

Adioetomo, S. M. (2005). Bonus Demografi Menjelaskan Hubungan antara Pertumbuhan Penduduk dengan Pertumbuhan Ekonomi. Pidato Pengukuhan Guru Besar Fakultas Ekonomi Universitas Indonesia, Jakarta.

Adioetomo, S. M. et al. (2010). 100 Tahun Demografi Indonesia: Mengubah Nasib Menjadi Harapan. Laporan BKKBN dan Lembaga Demografi FEB, Jakarta.

Adioetomo, S. M. \& Samosir, O. B. (Ed.). (2011). Dasar-Dasar Demografi (Ed. 2). Jakarta: Salemba Empat Bekerja Sama dengan Lembaga Demografi FEB UI.

Ananta, A. \& Arifin, E. N. (2009). A Demographic Window of Opportunity. Singapore: University of South East Asian Studies.

Badan Pusat Statistik (BPS). (2010). Sensus Penduduk Tahun 2010. Jakarta: BPS. 
Badan Pusat Statistik (BPS). (2014a). Kabupaten Landak Dalam Angka 2013. Pontianak: BPS.

Badan Pusat Statistik (BPS). (2014b). Survei Angkatan Kerja Nasional 2013: Propinsi Kalimantan Barat. Jakarta: BPS.

Blacker, C. P. (1947). Stages in Population Growth. The Eugenic Review, 39(3), 88-102.

Bloom, D. E., et al. (2003). The Demographic Dividend: A New Perspective on the Economic Consequences of Population Change. Santa Monica: RAND.

Bongaarts, J. (2003). Dependency Burdens in the Developing World. in Birdsall, K., Kelley, A. C. \& Sinding, S. (Eds.). Population Matters: Demographic Change, Economic Growth, and Poverty in the Developing World (pp.55-64). New York: Oxford University Press

Chandrsekhar, et al. (2006). The Demographic Dividend and Young India's Economic Future. Economic and Political Weekly, 5055-5064.

Diliberto, A, Pigliaru, F. \& Chelucci, P. (2008). International TFP Dynamics and Human Capital Stocks: a panel data analysis, 1960-2003 [Working Paper]. Diakses dari http://crenos.unica.it/crenos/publications/international-tfp-dynamics-and-humancapital-stocks-panel-data-analysis-1960-2003

Harian MEDIA INDONESIA (24 Juni 2015). 12.

Jong-11, K. \& L. J. Lau. (1996). The Sources of Asian Pacific Economic Growth. The Canadian Journal of Economics/Revue Canadienne d'Economique (Special Issue: Part 2), 29(April), S448-S454.

Kementerian Koordinator Bidang Kesra, 2011. Grand Design Pembangunan Kependudukan Tahun 2011-2035. Jakarta: Kementerian Koordinator Bidang Kesra

Khalifa, A. M. (2009). Youth Bulge and The Demographic Window Of Opportunity In The Arab World. Economic and Social Commission for Western Asia.

Kuncoro, A. \& Harmadi, S. H. B. (Eds.). (2016). Mozaik Demografi: Untaian Pemikiran tentang Kependudukan dan Pembangunan. Jakarta: Salemba Empat Bekerjasama dengan Lembaga Demografi FEB UI.

Lucas, D., et al. (1987). Pengantar Kependudukan (terjemahan). Yogyakarta: Gajah Mada University Press.

Mantra, I. B. (1994). Pengantar Kependudukan. Yogyakarta: CV. Tiara.

Mason, A. (Ed.). (2001). Population Change and Economic Development in East Asia. Challenge Met, Opportunities Seized. Stanford: Stanford University Press.

Todaro, M. P. \& Stephen C. S. (2011). Pembangunan Ekonomi (terjemahan) (Ed. 11). Jakarta: PT.Erlangga. 